\title{
Testicular Cancer by AJCC v8 Stage
}

National Cancer Institute

\section{Source}

National Cancer Institute. Testicular Cancer by A/CC v8 Stage. NCI Thesaurus. Code C140225.

A term that refers to the staging of testicular cancer according to the American Joint Committee on Cancer, 8th edition. This staging system applies to postpubertal germ cell tumors of the testis and malignant sex cord-stromal tumors of the testis. It does not apply to spermatocytic tumors (no AJCC staging system), nonmalignant sex cordIgonadal -stromal tumors (no AJCC staging system), prepubertal germ cell tumors (no AJCC staging system), hematolymphoid tumors (hematologic malignancies staging system), and paratesticular neoplasms (no AJCC staging system). (from AJCC 8th Ed.) 